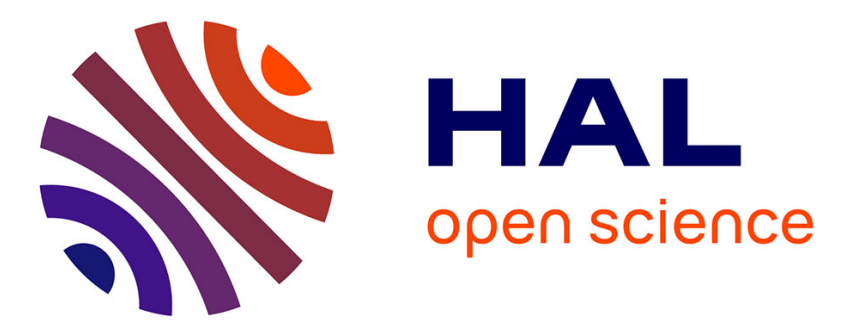

\title{
SHOULD I STAY OR SHOULD I GO? AN ECONOMETRIC ANALYSIS OF RETIREMENT DECISIONS BY COUPLES
}

Bérangère Legendre, Annaïg-Charlotte Pedrant, Mareva Sabatier

\section{- To cite this version:}

Bérangère Legendre, Annaïg-Charlotte Pedrant, Mareva Sabatier. SHOULD I STAY OR SHOULD I GO? AN ECONOMETRIC ANALYSIS OF RETIREMENT DECISIONS BY COUPLES. Applied Economics, 2018, 50 (53), pp.5814-5829. 10.1080/00036846.2018.1488067 . halshs-02374043

\section{HAL Id: halshs-02374043 \\ https://shs.hal.science/halshs-02374043}

Submitted on 21 Nov 2019

HAL is a multi-disciplinary open access archive for the deposit and dissemination of scientific research documents, whether they are published or not. The documents may come from teaching and research institutions in France or abroad, or from public or private research centers.
L'archive ouverte pluridisciplinaire HAL, est destinée au dépôt et à la diffusion de documents scientifiques de niveau recherche, publiés ou non, émanant des établissements d'enseignement et de recherche français ou étrangers, des laboratoires publics ou privés. 


\title{
SHOULD I STAY OR SHOULD I GO? AN ECONOMETRIC ANALYSIS OF RETIREMENT DECISIONS BY COUPLES
}

\author{
BERANGERE LEGENDRE ${ }^{1}$, ANNAIG-C. PEDRANT ${ }^{* 1}$, and MAREVA \\ SABATIER ${ }^{1}$ \\ ${ }^{1}$ IREGE - Université Savoie Mont Blanc - 4, chemin de Bellevue - BP 80439, 74944 Annecy-Le-Vieux Cedex
}

This paper analyzes retirement decisions from a household perspective, treating the retirement timing of spouses as potentially interdependent choices. To identify the determinants of retirement decisions by couples and the effects of spousal retirement, this research estimates bivariate probit models in a multi-country setting. The results show a significant joint retirement trend: Both men and women are more likely to retire if their spouse already has retired. Strong asymmetric behaviors arise by gender though, with high crosscountry heterogeneity, reflecting institutional differences in both pension and public health systems.

Key words: joint retirement decision, intra-household decision-making process, asymmetric behaviors, institutions.

JEL Codes: J26, D13, C35.

*Corresponding author: Annaig-Charlotte.Pedrant@univ-savoie.fr / + 33 (0)4 50092454

Berangere.Legendre@univ-savoie.fr

Mareva.Sabatier@univ-savoie.fr 


\section{Introduction}

The aging of the population and growing doubts about the sustainability of public pension systems have led to several reforms, designed to increase the entitlement retirement age in most developed countries. The success of such policies depends on how people respond to changes in their pension eligibility.

According to life cycle models (Seater, 1977 ; Bettendorf and Broer, 2003 ; Ljunqvist and Sargent, 2008 ; Hairault et al., 2010), postponing the legal age of retirement should reduce the distance effect automatically, thus producing a double dividend. That is, by extending the horizon to retirement age, this policy incites workers to delay their retirement and then incites firms to keep and train older workers for longer.

In reality though, several factors may limit these effects. Cox and Jimenez (1990) demonstrate that the full impact of programs for older workers can be assessed accurately only by taking the behaviors of all other family members into consideration. According to the economics of the family (Chiappori, 1988, 1992, 1997 ; Bourguignon et al., 1993, Alderman et al., 1995), no individual is a single decision maker, because interactions always take place among various household members with different preferences. These interactions seem particularly important between spouses, especially following the rise of female labor participation and the growth of dual-earner families in developed countries. Interactions between spouses, reflecting both income effects and leisure complementarities, suggest the possibility of spillover effects on the retirement strategies of older workers (Hurd, 1990). Spouses likely time their retirement closely together, leading to joint retirement trends among couples (Blau, 1998, Gustman and Steinmeier, 2000, 2014).

Omitting this family context could lead to overestimations of the impact of retirement eligibility rules on retirement decisions (Hospido and Zamarro, 2014). For example, Li and O'Donoghue (2011) report that in Ireland, increasing the minimum age for state pension entitlement from 65 to 70 years would delay retirement by about 1.8 years, according to an individual-based model, but by only about 0.5 years if intrahousehold interactions are considered. A better understanding of these retirement behaviors by couples thus might provide better guidance for policy makers (van der Klaauw and Wolpin, 2005 ; Blau and Gilleskie, 2006).

Despite growing literature that studies such joint retirement by spouses, no consensus is available regarding the magnitude of this phenomenon, its determinants, or the potential gender-based asymmetry in retirement behavior (Coile, 2004 ; Holtmann et al., 2006 ; Bingley and Lanot, 2007). Men and women respond differently to their household's characteristics and environment (Blau, 1998 ; Stancanelli and Van Soest, 2012), and determinants of joint retirement also depend on each country's specific social security system (Gustman and Steinmeier, 2004). For example, the basic pension scheme, or pension first pillar (Coile, 2015 ; Atalay and Barrett, 2016), exerts a powerful effect. In Europe, three main types of first pillars coexist.

First, the Beveridgian welfare state bases pensions on taxes (mainly in Anglo-Saxon and some northern European countries). Second, inspired by a Bismarck view, another first pillar defines earnings-related pensions (e.g., continental Europe). Third, for a first pillar based on notional accounts (e.g., Sweden), each individual invests some capital that gets converted, at retirement, into an annuity that depends on the retirement age and life expectancy. Different first pillars imply different contributions of the insured. Therefore, a particular pension scheme design might be particularly conducive to individualized decisions or not and thereby affect joint retirement decisions. The basic pension in traditional Beveridgian models is not contributive, which implies less individualized decisions. A basic pension could favor retirement if the amount is sufficient (Banks et al., 2010). With their basis in insurance principles, Bismarckian systems link contribution effort to benefits, which makes those pension schemes a bit more individualized, though joint retirements still could occur, depending on the potential financial support for the couple by a working spouse, which allows the first spouse to take an eligible pension (Stancanelli and Van Soest, 2012). Finally, pension systems based on individual notional accounts clearly are designed to favor individual choices (Selin, 2012). 
Regardless of which is the first pillar of a pension system, its operation can be disturbed by other areas of the social system, such as the health care system or family policies. For example, older workers tend to have higher expected medical expenditures (Kapur and Rogowski, 2007, Coe and Zamarro, 2011), so good health policies can offer appropriate solutions if one spouse falls ill, including benefits to favor early retirement or home-based care options.

In this context, this article seeks to analyze the joint retirement process for couples in a multi-country setting. We test not only if joint retirement exists, after accounting for all other factors that might explain retirement decisions, but also whether the potential for joint retirement differs according to the rules imposed by distinct social security systems and pension schemes.

To do so, we turn to the SHARE survey ${ }^{1}$ which describes couples and their retirement decisions across several countries. We focus attention on three: Denmark, France, and Sweden. These countries present some similarities but also distinct social security systems, which makes the comparison of households' behaviors in these three countries relevant for testing the joint retirement hypothesis. For example, Denmark, France, and Sweden all score relatively high on gender equality, compared with other European countries (Mills et al., 2014a ; Mills et al., 2014b). They all reach the Lisbon target in terms of female employment rate (60\%) and have relatively more equal earnings structures than other European countries. On the social policy side, Denmark, France, and Sweden also have embraced relatively equilateral and generous approaches. Finally, all three countries have adopted a pay-as-you-go pension system. Yet we also observe key differences in the first pillar. The Danish pension system is based on a basic pension, financed by general tax revenues and reduced for high income earners. Denmark thus seems to adopt a Beveridge view. French retirees instead receive an earning-related public pension, complemented by a compulsory occupational pension, offering a good example of the Bismarck tradition. Finally, Sweden represents an alternative scheme, in that it implemented notional accounts in 1998. Moreover, in all three countries, the health care systems are relatively generous, yet differences with regard to allowances for taking care of ill relatives are notable.

To test for joint retirement by spouses in these different institutional contexts, we estimate bivariate probit models for each country. As explanatory variables, we include the age difference between spouses, household outcomes and composition, and two variables that act on both spouses' decisions: distance to legal retirement age and health indicators. We find strong interactions by couples in their retirement decisions, whatever the country. However, the determinants of joint retirement differ across countries, due to institutional differences.

The rest of the article is structured as follows. The next section precises the theoretical framework of joint retirement into couples. Section 3 presents the data and the empirical analysis and section 4 concludes.

\section{Joint retirement by couples: a brief review}

Retirement decisions often get analyzed as an individual trade-off between the costs and benefits of retirement versus remaining in employment, without considering how family dimensions might affect such decisions. This purely individual view, as manifested in life cycle models (Modigliani and Brumberg, 1954 ; Merton, 1971), is challenged by theory regarding the economics of the family (Chiappori, 1988, 1992, 1997 ; Bourguignon et al., 1993, Bourguignon et al., 2009 ; Browning, 2000 ; Browning and Gortz, 2012), which shows that most decisions take place at a collective level within households, depending on the charac-

\footnotetext{
1 This paper uses data from SHARE Waves 5 (DOIs: 10.6103/SHARE.w5.500), for methodological details, see Börsch-Supan et al. (2013 Borsch-Supan et al. (2013), 2015 Borsch-Supan et al. (2015))and Malter and Börsch-Supan (2015 Malter and Borsch-Supan (2015)). The SHARE data collection was funded primarily by the European Commission through FP5 (QLK6 - CT - 2001 - 00360), FP6 (SHARE - I3:RII - CT - 2006 - 062193, COMPARE : CIT5 - CT - 2005-028857, SHARELIFE : CIT4 - CT - 2006 - 028812) and FP7 (SHARE - PREP : N211909, SHARE - LEAP : N227822, SH AREM4:N261982). Additional funding from the German Ministry of Education and Research, the U.S. National Institute on Aging $\left(U 01_{A} G 09740-13 S 2, P 01_{A} G 005842, P 01_{A} G 08291, P 30 A G 12815, R 21_{A} G 025169, Y 1-A G-4553-01, I A G B S R 06-\right.$ $11, O G H A_{0} 4-064$ ) and from various national funding sources is gratefully acknowledged (see www.share-project.org)
} 
teristics and bargaining power of each spouse. The economics of the family thus fills an important literature gap, revealing that retirement decisions depend on the collaboration among household members, who have different preferences. By collaborating, households' members can allocate their time, between remaining at work and retiring. In this conceptual framework, three main sources lead to retirement coordination by couples (Hurd, 1990).

First, due to their similar preferences, spouses may value retirement planning similarly. According to Goux and Maurin (2003), people tend to marry partners with similar socio-economic characteristics and personal preferences. Such marital homogamy could create positive assortative mating trends (Mascie-Taylor and Vandenberg, 1988) and lead to favor joint retirement.

Second, joint retirement can be linked to leisure complementarities between spouses, which occur if both spouses value their partner's presence and want to spend their leisure time together (Hurd, 1990). Each spouse's utility thus depends on the partner's status, which influences the trade-off between the cost and expected benefits of all household members (Gustman and Steinmeier, 2000 ; Michaud and Vermeulen, 2010). This leisure complementarity between spouses also could lead to retirement coordination, to maximize individual utility in the form of shared time.

Third, a retirement decision may depend on financial incentives, such as public retirement or health policies. A change in these incentives could generate a common shock on the household's budget and the bargaining power of each spouse (Chiappori, 1988, 1992, 1997 ; Bourguignon et al., 1993 ; Manski, 1993 ; Dahl et al., 2010). Thus, it may influence the efficient allocation of resources and create cross-spouse incentives (Hurd, 1990 ; Coile, 2004).

Together, these three mechanisms should lead to a positive correlation of the retirement dates of couples (Becker, 1973 ; Hurd, 1990 ; Manski, 1993), as is confirmed in several empirical studies (Hurd, 1990 ; Gustman and Steinmeier, 2000). Recently, Hospido and Zamarro (2014) find that the probability of women leaving the labor force increases by 16-18 percentage points when their husbands also stop working; a similar but less precise effect arises for men. They also estimate that controlling for spouses' working status reduces the impact of one's own eligibility for retirement pensions on the probability of leaving the labor force by 3 or 4 percentage points for early retirement and by 6 or 3 percentage points for full retirement pensions for men and women, respectively.

But extant empirical literature does not explain why such joint retirement exists and what mechanisms cause it. Empirical studies confront a major difficulty, due to the strong asymmetrical behaviors that appear within couples. For example, Stancanelli and Van Soest (2012) study leisure complementary and conclude that a husband's retirement does not increase the joint leisure hours of the couple, but the retirement of the wife significantly does. Traditional gender roles within households might explain why the determinants of retirement timing differ for each spouse(Talaga and Beehr, 1995 ; Dentinger and Clarkberg, 2002 ; Pozzoli and Ranzani, 2009). In settings marked by traditional roles, men provide financial support for the household, whereas women offer more psychological or physical assistance. In this framework, men's retirement decisions exert a greater influence on women's decisions, and the influence is even stronger if a spouse suffers health problems (Johnson and Favreault, 2001 ; Van Rijn et al., 2014). Dentinger and Clarkberg (2002) show, using U.S. data, that wives caring for their husbands are five times more likely to retire than women who are not caregivers, whereas husbands caring for their wives are substantially slower to retire. However, the prevalence of this caregiver role for women is decreasing. Because their careers in labor markets often are incomplete, women have fewer pension opportunities (O'Rand and Henretta, 1982 ; Aliaga, 2005). Most women marry older men, so wives would retire at a younger age than their husbands if they coordinated their retirement timing (Ruhm, 1996). In this sense, joint retirement could be a very costly option for women. In the United States, Johnson and Favreault (2001) report that household members are less likely to retire if their spouse leaves the labor force because of health problems, especially if that spouse is not yet eligible for Social Security retirement benefits. Finally, because women face more financial constraints 
than men, spouses perceive financial retirement incentives in asymmetrical ways, related to their partner situation (Blau, 1998 ; Coile, 2004). The retirement incentives of each spouse affect their own retirement decisions and their spouses. If men seem sensitive to spillover effects from their spouses (Coile, 2004), the same might not be true of women. Instead, women appear influenced more by their own economic variables when making retirement decisions, not merely following their husbands (Gustman and Steinmeier, 2000 ; Coile, 2004). According to Bloemen et al. (2015), wives respond to husbands' choices at ages when they are likely eligible for early retirement programs. Only social systems limiting the financial constraints of women can encourage joint retirement in this case.

As this literature reveals, joint retirement clearly exists among couples, but gender asymmetries in behaviors and the impact of institutional systems and incentives make it difficult to identify the specific determinants of this coordination. By exploiting data from an European survey, we attempt to overcome this theoretical gap with a multi-country study.

\section{Data and descriptive statistics}

We use the last wave (Wave 5, 2013) of the Survey on Health, Ageing and Retirement in Europe (SHARE), which includes people belonging to households with at least one member who is 50 years of age or older. For several reasons, SHARE is well-suited to assess elder couples' behaviors across countries. First, the cross-national panel database includes 20 European countries. Second, it provides information about couples, by matching each respondent with his or her partner. Third, SHARE indicates the economic situation of the respondents, their health status, and some sociological data. To account for the impact of the institutional context, we conduct a multi-country analysis of Denmark, France, and Sweden. As noted previously, these countries feature some social similarities, such as gender equality in employment, achieved through reforms that were designed to decrease disincentives to female labor force participation. In 2010, all three countries nearly reached the Barcelona targets ${ }^{2}$ in terms of childcare indicators, making them European leaders when it comes to these social politics (Mills et al., 2014a). Furthermore, they all have reached the Lisbon target in terms of female employment rate $(60 \%)$, with relatively higher female labor force participation rates than other European countries: 76\% in Denmark, 67\% in France, and 79\% in Sweden, versus $62 \%$ on average in OECD countries (2014 data). Denmark, France, and Sweden also feature relatively more equal earnings structures across couples than other European countries. According to Mills et al. (2014b), the shares of male sole provider households in these three countries are among the lowest in Europe (7\% in Denmark, 12\% in France, and 8\% in Sweden, compared with 21\% in UE27 in 2010). The share of relatively equal earnings structures accordingly is higher too: $43 \%$ in Denmark, 36\% in France, and 35\% in Sweden, compared with $28 \%$ in UE27 (2010 data).

On the social policy side, Denmark, France, and Sweden also have adopted relatively equilateral, generous systems compared with other developed countries. For their pension systems, all three countries rely on pay-as-you-go systems. However, institutional differences may influence retirement decisions. For example, the Danish pension system includes a public basic scheme, complemented by individual contributions. A compulsory occupational scheme, negotiated as part of collective agreements, also complements the base pension. The French retirement system primarily reflects a state pension scheme, depending on the sector of activity. The state pension is calculated on the basis of the personal wage, rate of contribution, and length of contribution. Mandatory supplementary schemes also complement this general state regime. In Denmark and France, recent reforms moved the legal retirement age. Specifically, Denmark's 2011 pension

\footnotetext{
${ }^{2}$ The Barcelona targets, defined in March 2002, recommend providing childcare to encourage gender equality and promote female labor participation. The specific targets for 2010 were to provide childcare to at least $90 \%$ of children between 3 years of age and the mandatory school age, as well as to at least $33 \%$ of children younger than 3 years.
} 
reform postponed the legal retirement at 67 years for those born after June 1960. In France, with its 2010 pension reform, the legal retirement age became 62 for people born after 1955, compared with 60 before (The Appendix contains the reform agendas in France and Denmark). In contrast, the Swedish pension system is based on defined contribution schemes, such that individual contributions get virtually capitalized in accounts that earn a notional rate of return, set by the government. Since 1994, Swedish people have been authorized to retire at the age of 61 years.

Finally, all three countries have generous health care systems, which is important for studies of elderly citizens, and they offer benefits to take care of ill relatives. But again, some differences emerge. In Denmark, the care allowance represents almost $50 \%$ of men's wages and $60 \%$ of women's earnings. In France, the health system grants family solidarity leave and an allowance of 55 euros per day, nearly the French minimum wage. Additional allowances may be added, such as pensions for disabled adults. Sweden's scheme is the most generous, in that municipalities compensate family caregivers directly by employing them, for an allowance of nearly 30 euros per hour of work, higher than the hourly median wage of just less than 20 euros.

In each country, we select a sample of married couples living together who both responded to the survey. Due to our focus on spouses' choices to remain at work or retire, we exclude inactive, unemployed, and disabled respondents. We thus gather information about 1008 couples in Denmark, representing $48.8 \%$ of the original Danish sample; 902 French couples, or $40.6 \%$ of the initial French sample; and 1071 Swedish households, corresponding to $42.3 \%$ of the sample. Tables 1 details some household and individual characteristics, respectively.

Our key variables pertain to the activity status of each partner in the household. Let $y_{i}^{m}$ and $y_{i}^{w}$ define the status of men $(m)$ and women $(w)$ in a given household $i$. These binary variables are equal to 1 when an individual $j$ (where $j=m, w$ ), in couple $i$ is retired and 0 if employed. Descriptive statistics (see the Appendix) reveal some country differences. In the Danish sample for example, $52 \%$ of respondents are retired, but $66 \%$ are in Sweden and 70\% are in France. The proportion of retirees thus appears lower in Denmark, which might reflect the age composition of the respondents. People younger than 60 years represent $37.5 \%$ of the Danish sample, versus 26.5\% in France and 19.5\% in Sweden.

More interesting are the statistics by gender. The retirement ages of men and women are similar in all three countries, though women appear to be three years younger than their spouses on average (Table 1). But the age difference at retirement is less than two years, and more than $15 \%$ of couples exit the labor force the same year. This finding suggests coordination in spouses' retirement timing, as well as that women retire younger.

\section{[TABLE 1]}

To add nuance to this finding, we also analyze of retirement age density by gender in each country (Figure 1).

\section{[FIGURE 1]}

According to these findings, the coordination of retirement decisions is particularly evident in Denmark, but less so in France or Sweden. Institutional differences could explain these findings. That is, in Denmark, the retirement age distributions of men and women differ, with a peak around 60 years (i.e., before the legal retirement age of 65 years), yet this peak is much more pronounced for women. Danish women thus seem to retire earlier than men, which may indicate joint retirement by couples and perhaps women's tendency to assume caregiving roles through early retirement. Bingley et al. (2004) similarly show that several Danish institutional schemes allow for early retirement (e.g., public employment pension, postemployment wage pension), without strong financial sanctions. In France, the retirement age distributions 
indicate a peak around the legal retirement age of 60 years, but more women (than men) wait to reach 65 years, and thus the full rate pension, to withdraw. Women tend to have more discontinuous careers, so French women might be incited to remain at work to maximize their financial retirement planning (Aliaga, 2005). Financial constraints seemingly exert a strong influence on retirement decisions in France. Finally, in Sweden, a larger portion of women (than men) tends to retire between 62 and 65 years, signaling potential joint retirement. But retirement age distributions are centered around 65 years, for both men and women. This finding aligns with the Swedish pension system, that is, an individualized contributory system based on notional accounts, such that it favors individual behaviors.

These influential institutional differences motivate our multi-country analysis. To identify potential joint decisions, we estimate three (one for each country) bivariate probit models (Heckman, 1978), in which we analyze the husband's and wife's probabilities of being retired ( $y_{i}^{j}$ with $j=m, w$ ) simultaneously, according to individual, spouse, household, and institutional variables. Specifically,

$$
\left\{\begin{array}{l}
\operatorname{Prob}\left(y_{i}^{m}=1\right)=\beta_{m}^{\prime} X_{i}^{m}+\delta_{m} Z_{i}+\lambda_{m} T_{i}^{w}+\epsilon_{i}^{m} \\
\operatorname{Prob}\left(y_{i}^{w}=1\right)=\beta_{w}^{\prime} X_{i}^{w}+\delta_{w} Z_{i}+\lambda_{w} T_{i}^{m}+\epsilon_{i}^{w}
\end{array}\right.
$$

Where :

- $m, w$ and $i$ indexe respectively men, women and couples ;

- $X_{i}^{j}$ includes individual attributes at the time of the interview ;

- $Z_{i}^{j}$ contains household's characteristics ;

- $T_{i}^{m}$ is a vector of partner' attributes ;

- $\epsilon_{i}^{m}$ and $\epsilon_{i}^{m}$ are errors terms supposed to be drown from a bivariate normal distribution with:

$$
\operatorname{Cov}\left[\epsilon_{i}^{m}, \epsilon_{i}^{w} \mid x_{i}^{m}, x_{i}^{w}\right]=\rho
$$

The coefficient $\rho$ reflects the correlation between spouses' retirement decisions within the couple, to capture the potential spillover effect (Gustman and Steinmeier, 2000 ; Coile, 2004 ; Li and O’Donoghue, 2011).

With regard to the observed variables included to explain retirement decisions (vectors $X_{i}^{j}$ and $T_{i}^{j}$ ), we include education to capture the effects of human capital, which proxies for income and consequently the bargaining power of spouses within the household. This variable is based on the International Standard Classification of Education (ISCED 1997) from UNESCO, with three categories: low (none, preprimary, and primary education), medium (lower secondary/secondary), and high (tertiary) education. We also introduce a health indicator, because health problems have direct effects on retirement decisions and on the spouse's decision, according to who takes the caregiver role. We choose an objective health indicator, namely, the number of chronic diseases (e.g., diabetes, hypertension, arthritis). Finally, we estimate separate equations for each country to capture institutional differences, but we also account for the institutional context from an individual perspective, which likely has a strong impact on retirement decisions, according to both life cycle models and Figure 1 . That is, as an explanatory variable, we include the (time) distance to the legal age of retirement, calculated according to the legal rules in each country, and equal to 0 if the person is already retired. The SHARE data set provides the dates of the interview and the respondent's birth, so we can calculate this distance $D_{i}^{j}$ precisely, using individual $i$ 's birth month and year:

$$
D_{i}^{j}=\text { legal age of retirement } t_{i}^{j}-\text { age }_{i}^{j}
$$

In addition to individual variables, we consider household attributes $\left(Z_{i}^{j}\right)$ as explanatory factors. In particular, the age difference between spouses could act as a barrier to the joint retirement process, especially 
when it comes to pension rights. A household budget constraint also is included, according to the household's gross financial assets per capita. Finally, we take intergenerational ties into account. Older workers generally are not concerned with the presence of dependent children, but we introduce the presence of grandchildren as a potentially pertinent factor.

To robustly identify our results, we estimate conditional odds ratios to compare the impact of some key explanatory variables on retirement estimated probabilities. This allows us to test the significant difference between spouses' behaviors.

\section{Results}

The results from the bivariate probit models are in Table 2. Each column presents the results for Denmark, France, and Sweden. The robustness of the findings is affirmed by the correct prediction rates, which are greater than $80 \%$ for all three countries. The marginal effects and conditional odds ratios are in the Appendix.

To compare the results from the three countries, we begin with how individual characteristics affect retirement decisions $\left(X_{i}^{j}\right)$. Human capital has a role, especially in Sweden (both men and women) and France (men only). The most educated are less likely to retire, probably because they have more employment opportunities. We also find a significant distance effect, such that retirement decisions depend on the person's own distance to the legal retirement age: The shorter the distance, the higher the retirement probability. Thus, postponing the legal retirement age should incite people to delay their retirement. However, this reform also could affect spouses in some countries. Health influences retirement decisions too, such that people suffering from chronic diseases are more likely to retire, due to their strong labor disutility or need for care. Moreover, health sometimes interacts with the distance effect, especially for women. The effects of this interaction differ according to the country studied though, so they may be linked to institutional differences in social care systems.

\section{[TABLE 2]}

But the major result of our study is to highlight that retirement decisions depend not only on individual attributes but also on household characteristics $\left(Z_{i}^{j}\right)$.

In turn, we note that household gross financial assets can influence individual retirement decisions, though not in all countries. We find a significant, negative effect of this characteristic in Denmark (men and women) and Sweden (men only), but not in France. In the two first countries, some of the pension system is based on individual contributions, so remaining employed could increase these contributions, especially if the household has substantial assets. But in France, where the system is based on public pensions and mandatory occupational schemes, household gross financial assets are not significant for either spouse. Our results are in line with Blanchet and Debrand (2007) : Depending on the pension system, the scale of pension rights is a major determinant of retirement planning.

Having grand-children seems to exert a weak effect (cf. Denmark), but retirement decisions depend strongly on the spouse's status and attributes. In all three countries, we note the strong correlation of retirement choices between spouses. The error terms for the spouses' equations are significantly and positively correlated $(\rho>0)$, indicating the presence of common unobservable preferences and a joint retirement process by couples (Hurd, 1990).

In all countries, but particularly in Sweden, the pension system is more individualized, but the spouse's situation directly affects both men's and women's retirement decisions. Thus, both observable spouse attributes and unobservable member preferences influence retirement choices, despite the strong country heterogeneity. 
Delving deeper into this interesting finding, we consider the spouse's attributes that may influence individual retirement decisions $\left(T_{i}^{j}\right)$, To start, for health status, we observe vast differences by gender but also across the three countries. In Denmark, a traditional role framework seems to apply, such that women adopt caregiver roles, and the probability that both spouses are retired increases by $3.6 \%$ when the husband suffers from poor health (see the marginal effects in the Appendix). The husband's probability of being retired instead decreases significantly when his ill wife is farther from her legal retirement age, suggesting that men provide financial support for the household. In France, and in contrast with Denmark, men assume a caregiver role. The probability of both spouses being retired increases by $11.2 \%$ when the wife has poor health; the husband's health is not significant. Finally, in Sweden, a spouse's poor health is a significant, positive determinant of retirement for both men and women. The probability of both spouses being retired increases by $2.7 \%$ and $7.1 \%$, respectively, when the husband or wife is in poor health. Women's health status has a stronger impact on the probably of joint retirement. Finally, husbands average three years older than their wives, suggesting a greater probability that men are closer to their own legal age of retirement. Thus retirement may be more likely when his wife experiences serious health troubles.

Those results are confirmed by conditional odds ratios, expected for Denmark where there is not significant difference between spouses' responses to the health of the partner ${ }^{3}$.

Country differences in the estimated impacts of spouses' health can be attributed to differences in the health care system. The generosity of the Swedish health care system allows both husbands and wives to display altruistic behaviors. If one spouse becomes ill, the public allowance compensates for the financial losses for the caregiver. In Denmark and France, the existing financial incentives seem insufficient to encourage altruistic behaviors. Because women face more financial constraints than men, they appear unable to respond to those incentives.

The legal retirement age also influences partners' decisions. In Denmark and France, we find strong gender asymmetry when it comes to the distance to retirement. In Denmark, a higher distance to the legal age of retirement for the wife decreases the probability that her husband is retired. Even though women tend to marry older men, husbands seemingly wait for their wives, to achieve joint retirement. When both spouses are retired, the marginal effect of the wife's distance is twice that of her husband's. Along similar lines, in France, the distance of the wife to retirement significantly decreases the probability that the husband is retired; the reverse is not significant. Women experience serious constraints on their access to pension rights, which induces these asymmetrical spousal spillover effects. In this sense, women appear influenced mainly by their own economic features when making retirement decisions. The distance of the wife decreases the probability of being simultaneously retired by $1 \%$. However, conditional odds ratios does not support the significant difference between spouses' behaviors because the magnitude of the effects for both spouses are too close.

Here again, Sweden is distinct, revealing no such asymmetry. The probability of both spouses being retired decreases with distance to the legal age of retirement of the spouse: $2.5 \%$ for the distance of the husband and $1.5 \%$ for the wife. Joint behaviors are dominant among Swedish couples. Public family policy appears to encourage this choice, thereby counteracting the individualized pension system. For example, one spouse may choose to transfer funded pension rights to the other, to facilitate early retirement for the younger partner. Thus joint retirement can be made easily accessible through a policy that complements pension rights systems.

\footnotetext{
${ }^{3}$ This only capture the own effect of the health variable and not the cross effect with the distance to the legal age.
} 


\section{Conclusion}

This article tests predictions of joint retirement by couples in a multi-country setting. Using SHARE data from Denmark, France, and Sweden - three countries with relatively equilateral and generous public, social, and retirement systems - we confirm the existence of a joint retirement process by couples, due to both observed and unobserved variables. Thus research must account for the family environment in individual retirement decisions, as recommended by the economics of family (Chiappori, 1992 ; Bourguignon et al., 1993).

We also highlight some strong asymmetries by gender, mainly related to institutional differences in social security systems. Men and women respond differently to incentives, according to each country's social system. Retirement rules influence spouses' decisions, but so do the rules of the health care system. Finally, when the social system seeks to incite spouses to be altruistic by giving a generous allowance to caregivers, both men and women coordinate their retirement timing. If public subsidies instead are low, only the spouse with lower financial constraints can anticipate retirement. Then, particularly for women in France, individual economic motivations dominate, and retirement occurs only upon the legal retirement age, and even for spouses who would prefer to retire together.

Our work thus suggests two key conclusions. First, retirement decisions must be viewed as a result of a collective decision process by couples. Neglecting this status could bias evaluations of the impact of public policies, with strong negative effects for people who are highly sensitive to these policies. Second, both pension rules and the health care system matter. An individualized pension system combined with a generous caregiver allowance (e.g., Sweden) can grant incentives to remain employed, exhibit altruism, and reduce the financial constraints faced by women. In contrast, a pay-as-you-go system (as in Denmark or even more so in France) could reinforce inequalities in couples, especially if any health problems occurs. Our results thus argue for the inclusion of the family dimension in defining social policies and coordinating these policies. 
Table 1: Average age and average age of retirement

\begin{tabular}{lcccccc}
\hline \multirow{2}{*}{$\begin{array}{l}\text { Countries } \\
\text { VARIABLES }\end{array}$} & \multicolumn{2}{c}{ Denmark } & \multicolumn{2}{c}{ France } & \multicolumn{2}{c}{ Sweden } \\
& Men & Women & Men & Women & Men & Women \\
\hline Average age & 65.81 & 63.22 & 67.63 & 65.03 & 69.45 & 66.74 \\
Observations & 1008 & 1008 & 902 & 902 & 1071 & 1071 \\
\hline \hline & & & & & & \\
Average age of retirement & 62.48 & 61.07 & 58.86 & 59.66 & 63.27 & 62.74 \\
Observations & 532 & 519 & 675 & 599 & 742 & 692 \\
\hline
\end{tabular}

Source : SHARE Survey, 2013

Figure 1: Density of the retirement age by country
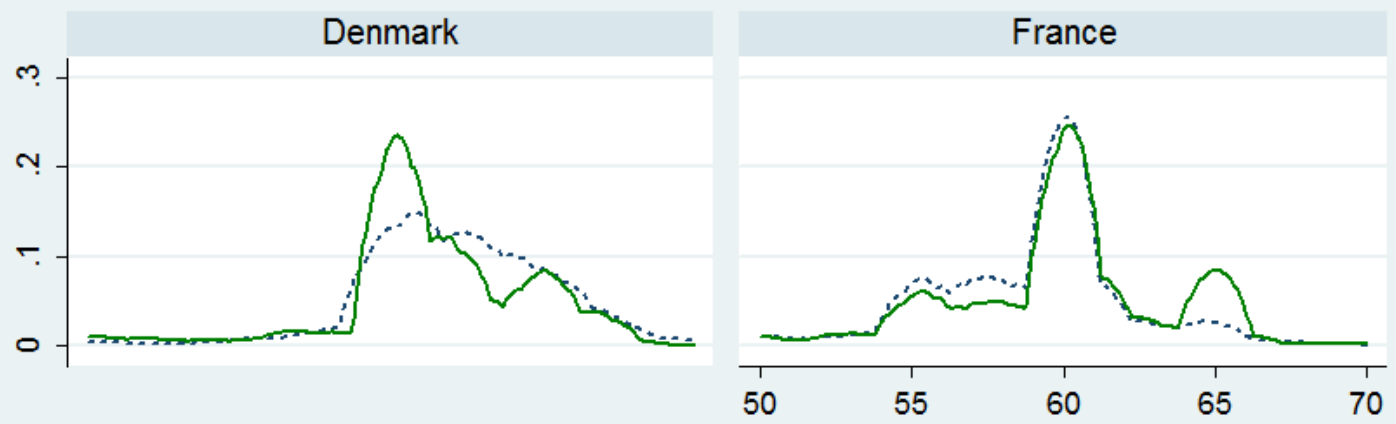

Sweden

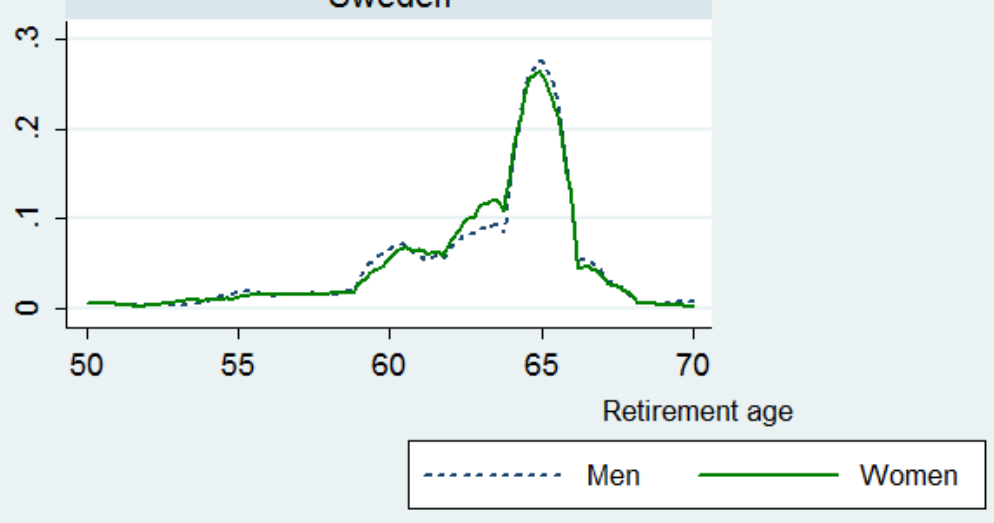

Source : SHARE Survey, 2013 


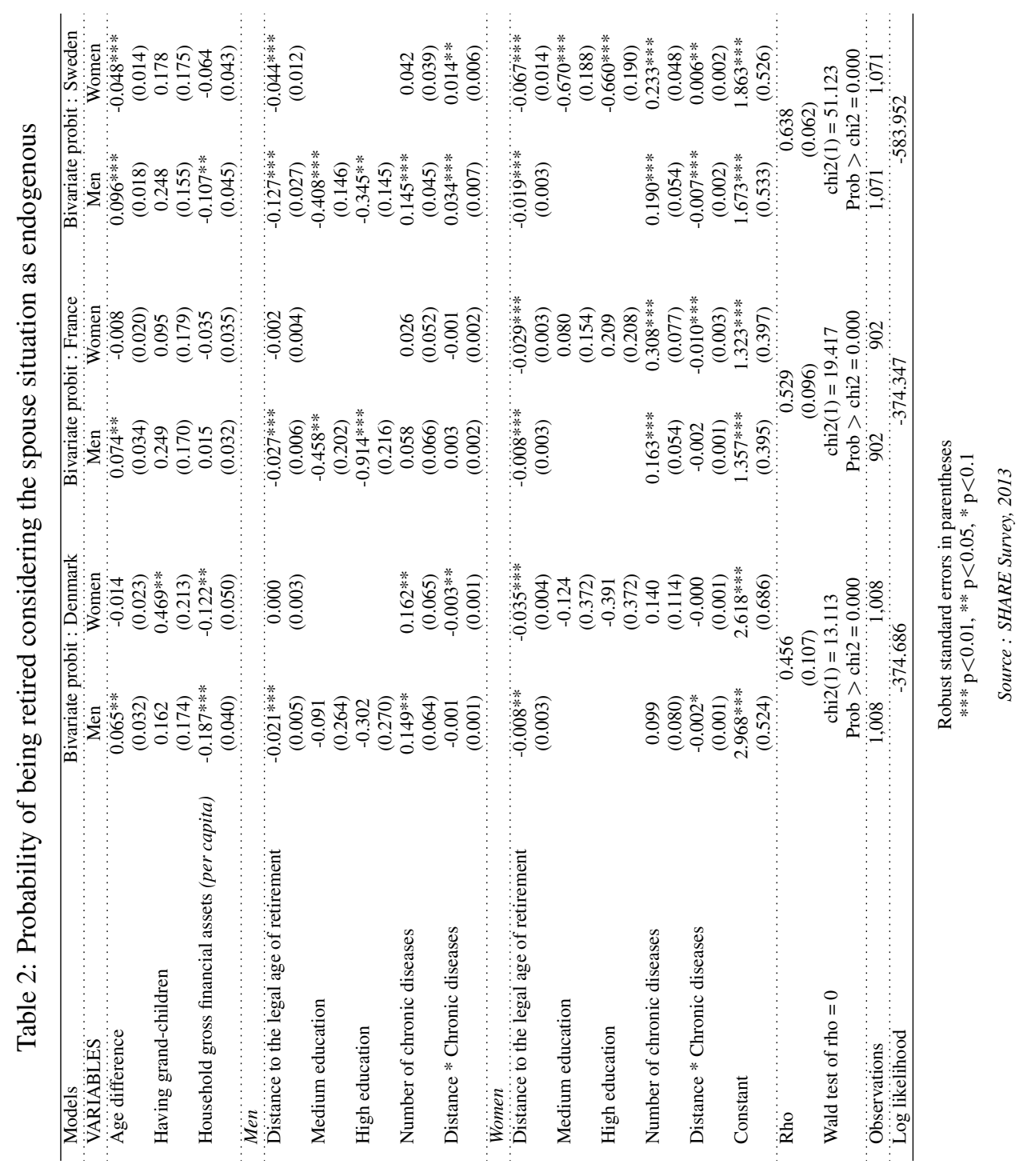


Appendices

A Variables 


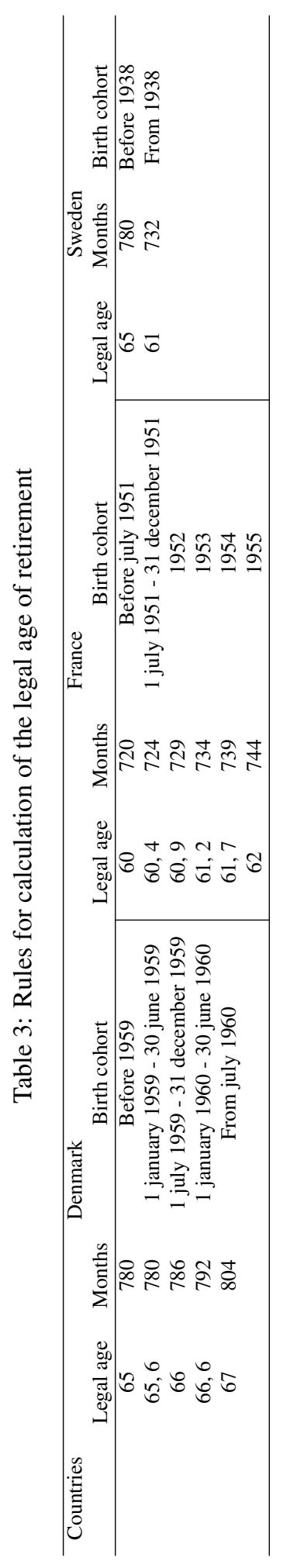


B Statistics 


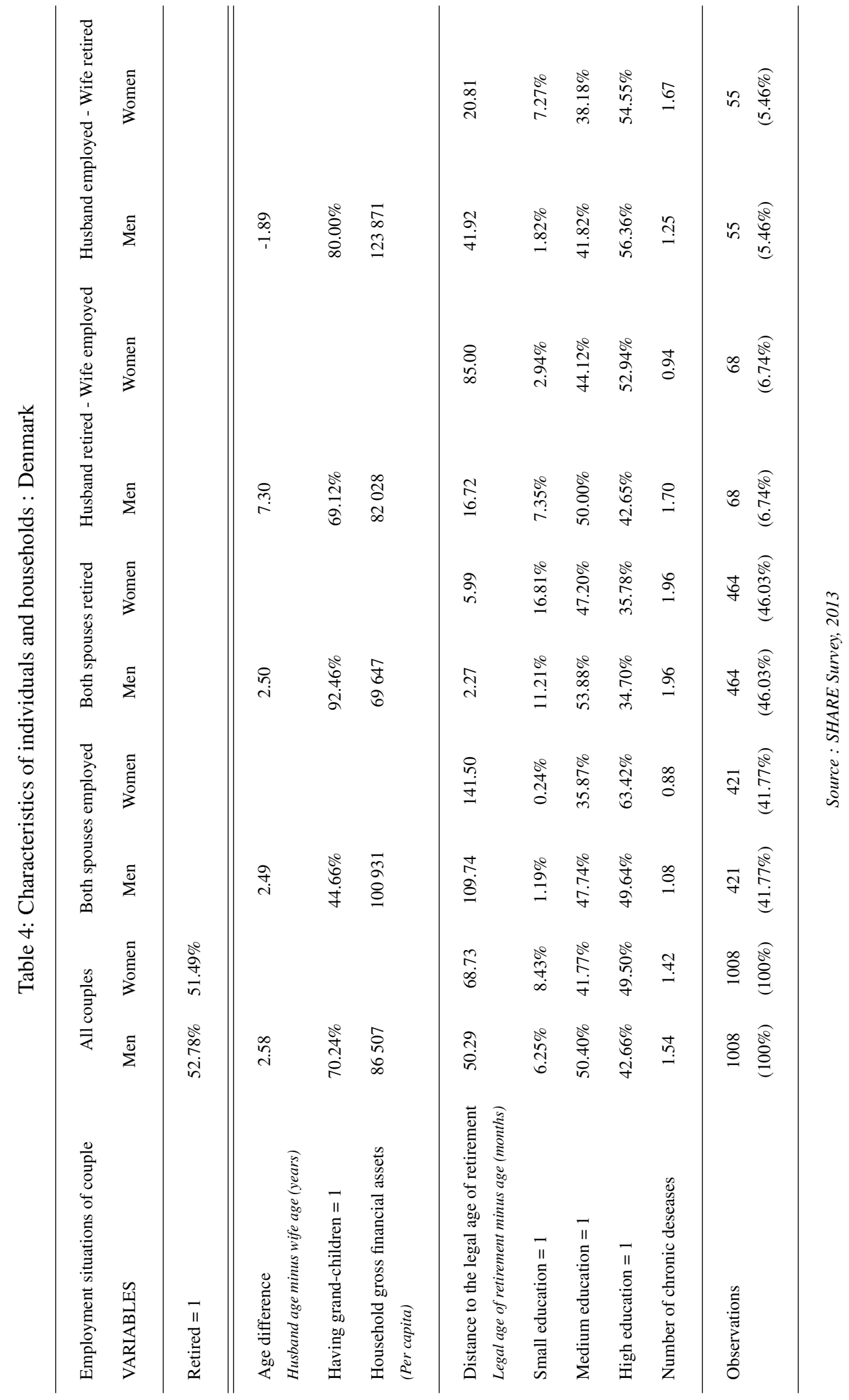




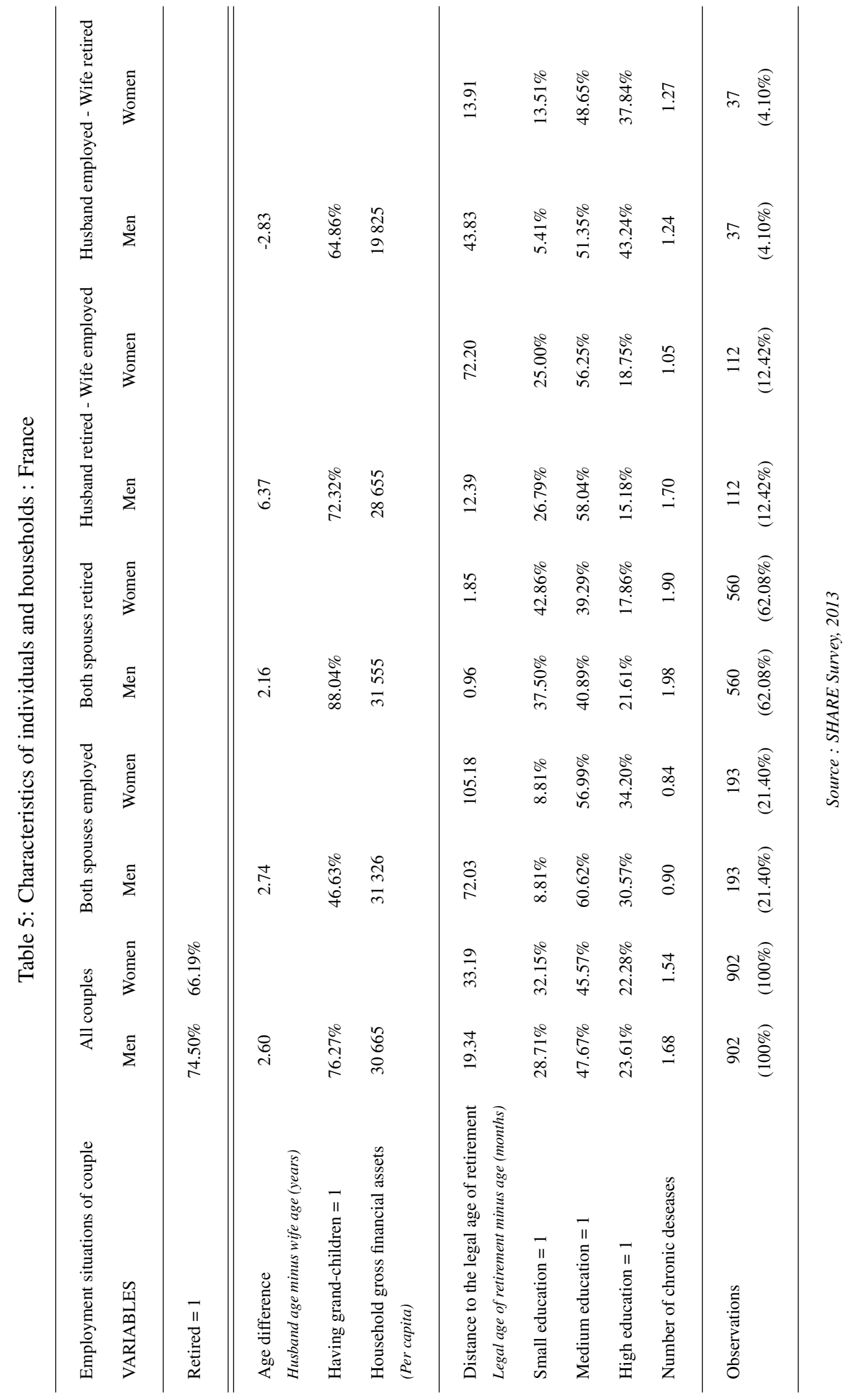




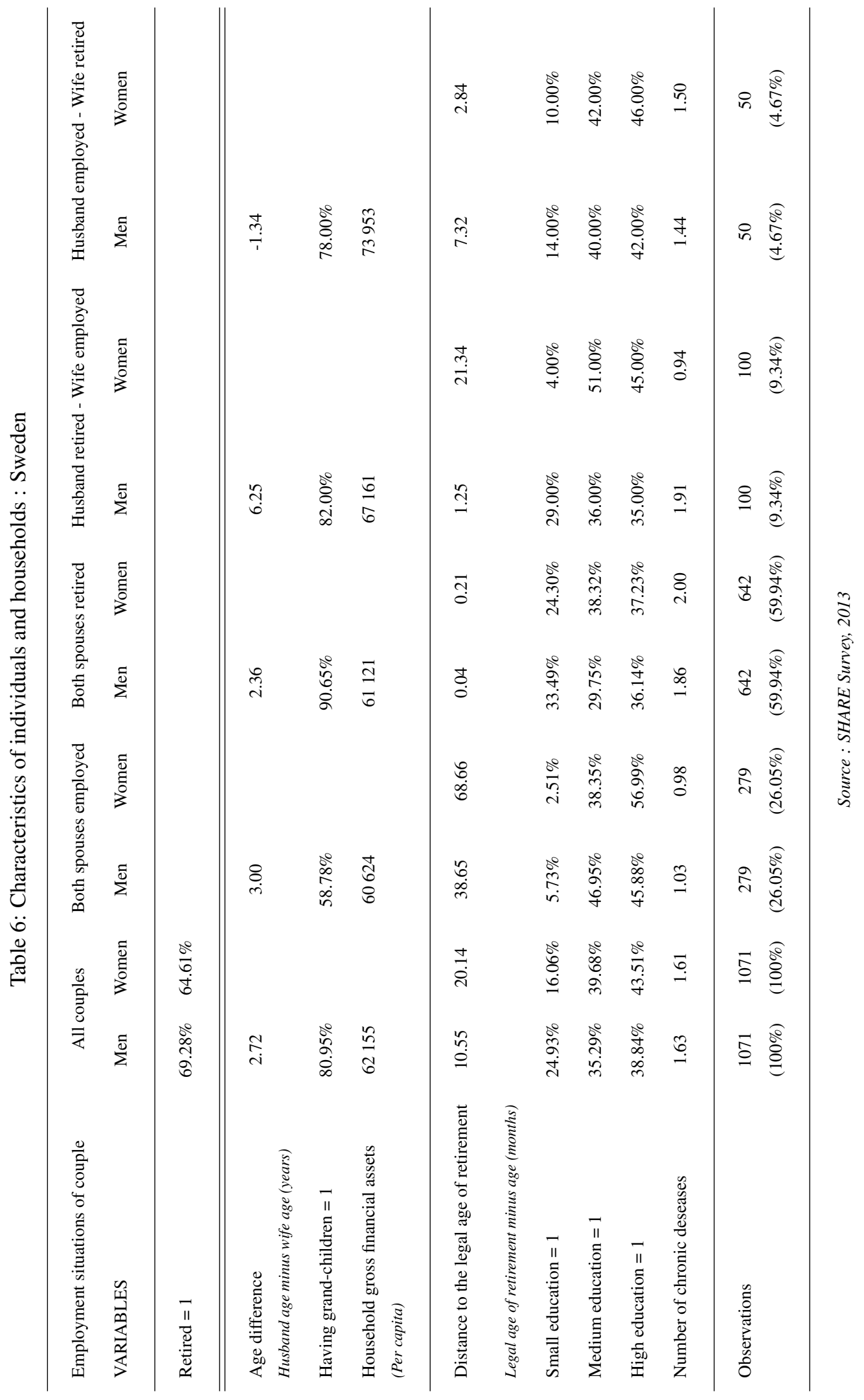


C Results 


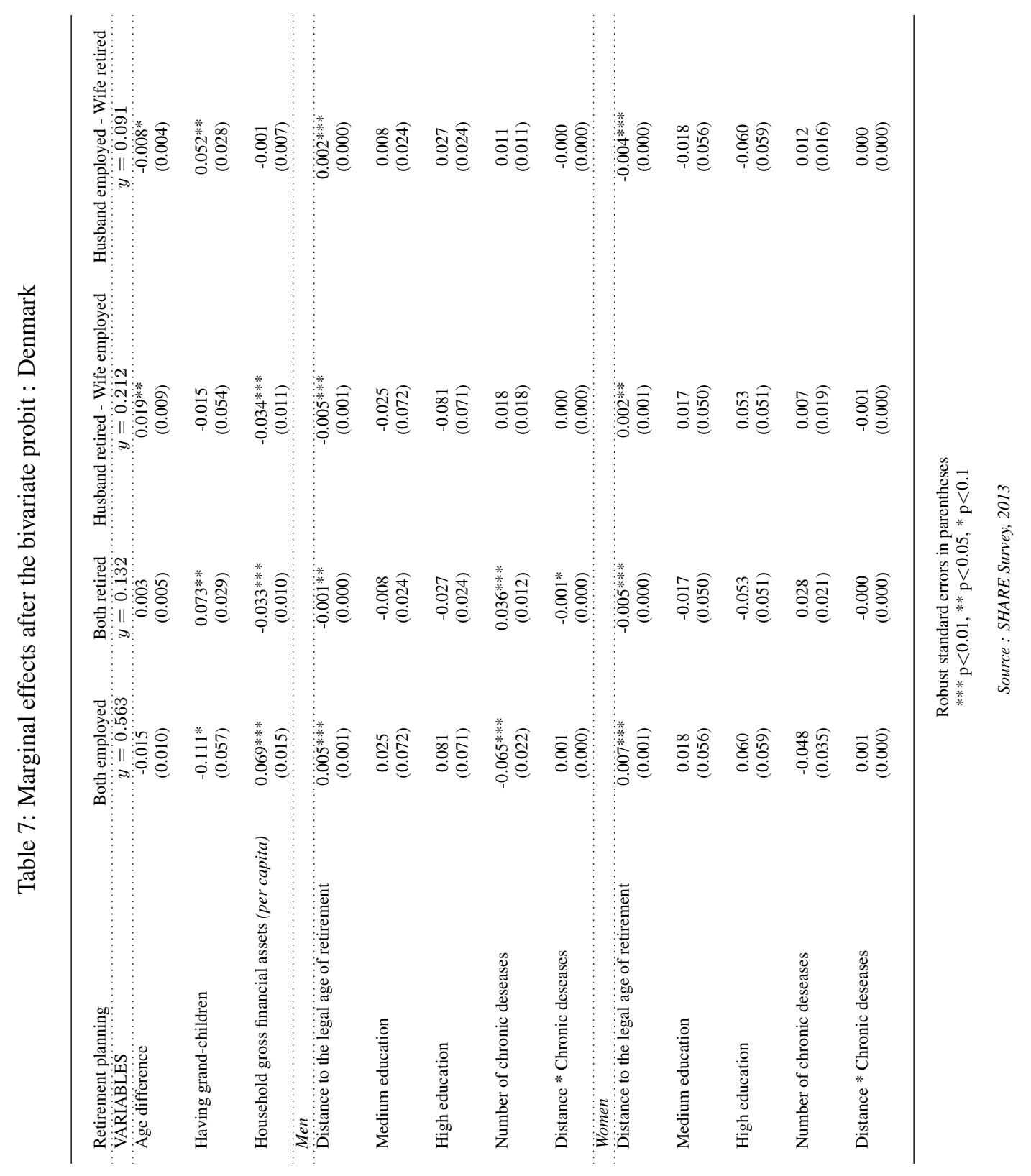




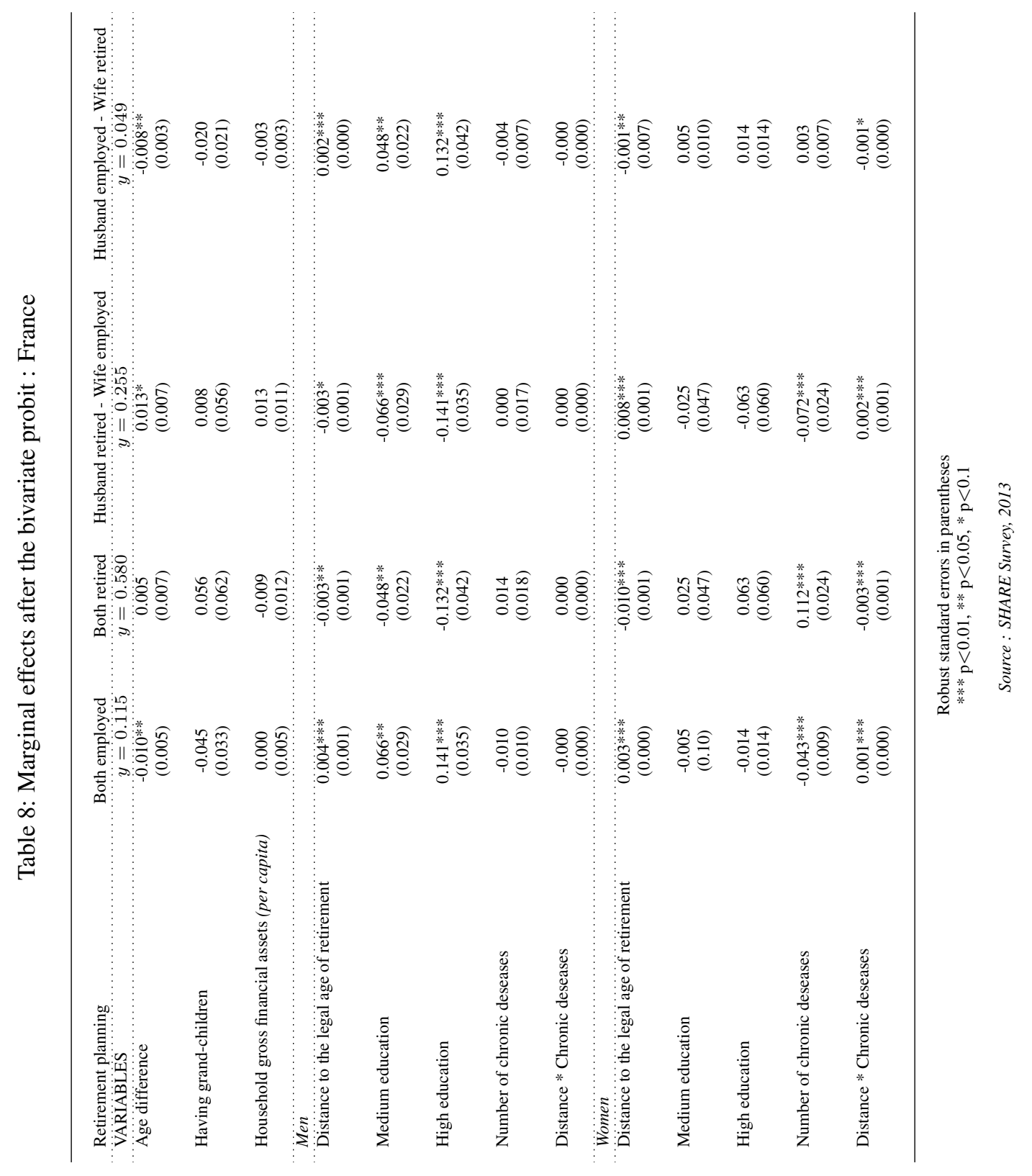




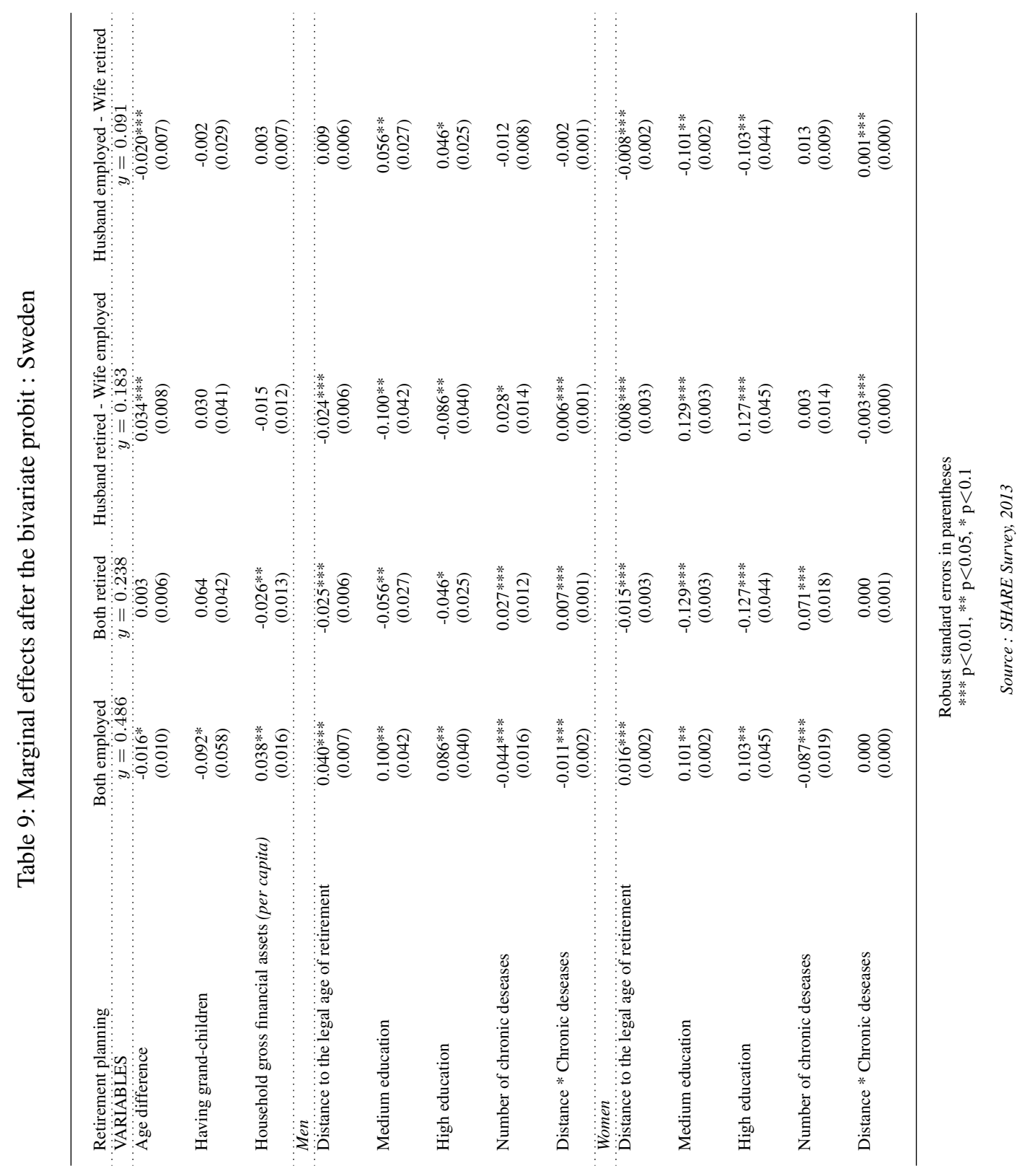


Table 10: Conditional odds ratios

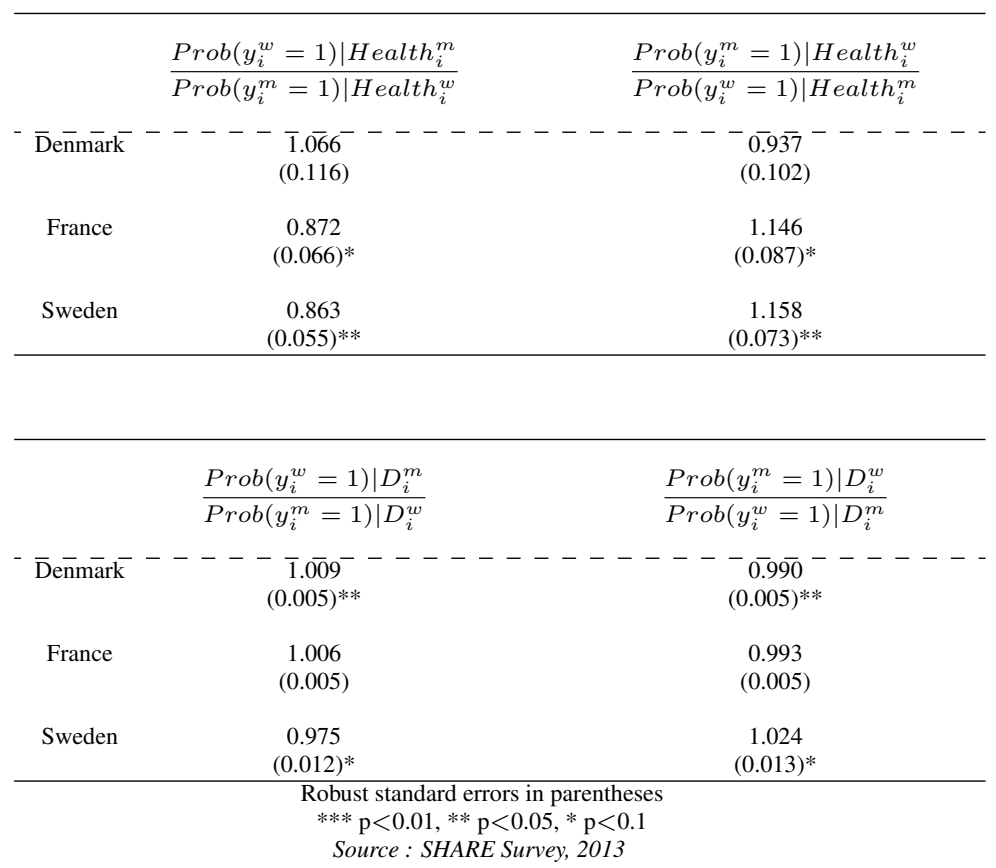

\section{References}

Alderman, H., Chiappori, P., Haddad, L., Hoddinott, J. and Kanbur, R. (1995), 'Unitary versus collective models of the household: is it time to shift the burden of proof ?', World Bank Research Observer 10, 119.

Aliaga, C. (2005), 'Conciliation entre vie professionnelle et vie familiale: des écarts entre les femmes et les hommes', Eurostat, Statistiques en bref 4.

Atalay, K. and Barrett, G. (2016), 'Pension incentives and the retirement decisions of couples', IZA - Institute for the Study of Labor (10013).

Banks, K., Blundell, R. and Casanova Rivas, M. (2010), 'The dynamics of retirement behavior in couples: Reduced-form evidence from england and the us', University College London Working Paper p. 39.

Becker, G. (1973), 'A theory of marriage: part I', Journal of Political Economy 81(4), 813-846.

Bettendorf, L. and Broer, D. (2003), Lifetime labor supply in a search model of unemployement. OCFEB Research Memorandum 0308.

Bingley, P., Datta Gupta, N. and Pedersen, P. (2004), 'The impact of incentives on retirement in denmark', Social Security Programs and Retirement around the World: Micro-Estimation, Author/Editor: Jonathan Gruber and David A. Wise editors, University of Chicago Press.

Bingley, P. and Lanot, G. (2007), 'Public pension programmes and the retirement of married couples in denmark', Journal of Public Economics .

Blanchet, D. and Debrand, T. (2007), 'Souhaiter prendre sa retraite le plus tot possible. sante, satisfaction au travail et facteurs monetaires', Economie et Statistique (403-404). 
Blau, D. (1998), 'Labor force dynamics of older married couples', Journal of Labor Economics 16(3).

Blau, D. and Gilleskie, D. (2006), 'Health insurance and retirement of married couples', Journal of Applied Econometrics.

Bloemen, H., Hochguertel, S. and Zweerink, J. (2015), 'Joint retirement of couples: Evidence from a natural experiment', IZA - Institute for the Study of Labor (8861).

Borsch-Supan, A., Brandt, M., Hunkler, C., Kneip, T., Korbmacher, J., Malter, F., Schaan, B., Stuck, S. and Zuber, S. (2013), 'Data resource profile: The survey of health, ageing and retirement in europe (share)', International Journal of Epidemiology. DOI: 10.1093/ije/dyt088.

Borsch-Supan, A., Kneip, T., Litwin, H., Myck, M. and Weber, G. (2015), 'Ageing in europe - supporting policies for an inclusive society', Berlin: De Gruyter. .

Bourguignon, F., Browning, M. and Chiappori, P. A. (2009), 'Efficient intra-household allocations and distribution factors: implications and identification', Review of Economic Studies, Oxford University Press 76(2), 503-528.

Bourguignon, F., Browning, M., Chiappori, P. and Lechene, V. (1993), 'Intra household allocation of consumption: a model and some evidence from french data', Annales d'Economie et de Statistique 29, 137156.

Browning, M. (2000), 'The saving behaviour of a two-person household', The Scandinavian Journal of Economics 102(2), 235-251.

Browning, M. and Gortz, M. (2012), 'Spending time and money within the household', The Scandinavian Journal of Economics 114(3), 681-704.

Chiappori, P. (1988), 'Rational household labor supply', Econometrica 56(1), 63-90.

Chiappori, P. (1992), 'Collective labor supply and welfare', Journal of Political Economy 100, 437-467.

Chiappori, P. (1997), 'Introducing household production in collective models of labor supply', Journal of Political Economy 105, 191-209.

Coe, N. and Zamarro, G. (2011), 'Retirement effects on health in europe', Journal of Health Economics pp. 77-86.

Coile, C. (2004), 'Retirement incentives and couples' retirement decisions', Topics in Economic Analysis \& Policy 4(1).

Coile, C. (2015), 'Economic determinants of workers' retirement decisions', Journal of Economic Surveys 29(4), 830-853.

Cox, D. and Jimenez, E. (1990), 'Achieving social objectives through private transfers: a review', The World Bank Research Observer 5(2), 205-18.

Dahl, S., Nilsen, O. and Vaage, K. (2010), 'Work or retirement? exit routes for norwegian elderly', Journal of Applied Economics pp. 1865-1876.

Dentinger, E. and Clarkberg, M. (2002), 'Informal caregiving and retirement timing among men and women gender and caregiving relationships in late midlife', Journal of Family Issues 23, 857-879. 
Goux, D. and Maurin, E. (2003), Who marries whom? Educational systems as marriage markets in modern societies, Dordrecht, Kluwer Academic Publishers, chapter Who marries whom in France? An analysis of the cohorts born between 1934 and 1978, pp. 57-78.

Gustman, A. and Steinmeier, T. (2000), 'Retirement in dual-career families: a structural model', Journal of Labor Economics .

Gustman, A. and Steinmeier, T. (2004), 'Social security, pensions, and retirement behavior within the family', National Bureau of Economic, Research Working Paper 8772.

Gustman, A. and Steinmeier, T. (2014), 'Integrating retirement models: Understanding household retirement decisions', Research in Labor Economics 40, 79-112.

Hairault, J., Langot, F. and Sopraseuth, T. (2010), 'Distance to retirement and older workers' employment: The case for delaying the retirement age', Journal of the European Economic Association 8(5), 10341076.

Heckman, J. (1978), ‘Dummy endogenous variables in a simultaneous equation system', Econometrica 46(4), 931-959.

Holtmann, A., Ullmann, S., Fronstin, P. and Longino, C. (2006), 'The early retirement plans of women and men: an empirical application', Journal of Applied Economics pp. 591-601.

Hospido, L. and Zamarro, G. (2014), 'Retirement patterns of couples in europe', IZA - Institute for the Study of Labor (7926).

Hurd, M. (1990), Issues in the Economics of Aging, University of Chicago Press, chapter The joint retirement decision of husbands and wives, pp. 231-258.

Johnson, R. and Favreault, M. (2001), 'Retiring together or working alone: The impact of spousal employment and disability on retirement decisions', Center for Retirement Research at Boston College .

Kapur, K. and Rogowski, J. (2007), 'The role of health insurance in joint retirement among married couples', Industrial and Labor Relations Review, 60(3), 397-407.

Li, J. and O'Donoghue, C. (2011), 'Retirement choice simulation in household settings with heterogeneous pension plans', IZA - Institute for the Study of Labor $\mathbf{5 8 6 6 .}$

Ljunqvist, L. and Sargent, S. (2008), 'Two questions about european unemployment', Econometrica 76(1), 1-29.

Malter, F. and Borsch-Supan, A. (2015), 'Share wave 5: Innovations \& methodology', Munich: MEA, Max Planck Institute for Social Law and Social Policy .

Manski, C. (1993), 'Identification of endogenous social effects: The reflection problem', The Review of Economic Studies 60(3), 531-542.

Mascie-Taylor, C. and Vandenberg, S. (1988), 'Assortative mating for IQ and personality due to propinquity and personal preference', Behavior Genetics 18, 339-345.

Merton, R. (1971), 'Optimal consumption and portfolio rules in a continuous-time model', Journal of Economic Theory 3(4), 373-413.

Michaud, P. and Vermeulen, F. (2010), 'A collective labor supply model with complementarities in leisure: Identification and estimation by means of panel data', Labour Economics 18, 159-167. 
Mills, M., Prag, P., Tsang, F., Begall, K., Derbyshire, J., Kohle, L., Mian, C. and S., H. (2014a), Use of childcare in the eu member states and progress towards the barcelona targets, Technical Report RR-185EC, European Commission.

Mills, M., Tsang, F., Prag, P., Ruggeri, K., Mian, C. and S., H. (2014b), Gender equality in the workforce: Reconciling work, private and family life in europe, Technical Report RR-462-EC, European Commission.

Modigliani, F. and Brumberg, R. (1954), Post-Keynesian Economics, New Brunswick, NJ: Rutgers University Press, chapter Utility analysis and the consumption function: an interpretation of cross-section data.

O'Rand, A. and Henretta, J. (1982), 'Delayed career entry, industrial pension structure, and early retirement in a cohort of unmarried women', American Sociological Review 47, 345-373.

Pozzoli, D. and Ranzani, M. (2009), 'Old european couples' retirement decisions: the role of love and money', Working Paper.

Ruhm, J. (1996), 'Gender differences in employment behavior during late middle age', Journal of Gerontology pp. 11-17.

Seater, J. (1977), 'A unified model of consumption, labor supply, and job search', Journal of economic theory 14, 349-372.

Selin, H. (2012), 'Marginal tax rates and tax-favoured pension savings of the self-employed: evidence from sweden', The Scandinavian Journal of Economics 114, 79-100.

Stancanelli, E. and Van Soest, A. (2012), 'Joint leisure before and after retirement: A double regression discontinuity approach', IZA - Institute for the Study of Labor 6698.

Talaga, J. and Beehr, T. (1995), 'Are there gender differences in predicting retirement decisions ?', Journal of Applied Psychology 80(1), 16-28.

van der Klaauw, W. and Wolpin, K. (2005), 'Social security and the retirement and savings behavior of low income households', Penn Institute for Economic Research p. 89.

Van Rijn, R., Robroek, S., Brouwer, S. and Burdorf, A. (2014), 'Influence of poor health on exit from paid employment: A systematic review', Occupational and Environmental Medicine 71, 295-301. 